УДК 616-089

DOI: $10.18101 / 2306-1995-2020-1-48-56$

\title{
СЛУЧАЙ УСПЕШНОЙ РЕИМПЛАНТАЦИИ ЧЕТВЕРТОГО ПАЛЬЦА ПРАВОЙ КИСТИ
}

\section{(C) Кузнецов Сергей Миронович}

кандидат медицинский наук, врач хирург высшей категории, заведующий операционным отделением

s.m.kusnetzov@yandex.ru

\section{(С) Косолапов Юрий Леонидович}

подполковник медицинской службы, старший ординатор, хирург высшей категории y.kosolapov@mail.ru

\section{(C) Дармаев Андрей Дашиевич}

врач невролог высшей категории darmaevad@mail.ru

\section{(C) Гордеенок Федор Демидович}

ординатор хирургического отделения, заслуженный врач России, врач высшей категории s.m.kusnetzov@yandex.ru

\section{(C) Логинов Олег Станиславович}

хирург поликлинического отделения, врач высшей категории s.m.kusnetzov@yandex.ru

\section{(C) Зырянов Андрей Анатольевич}

ординатор отделения АиР, врач анестезиолог высшей категории s.m.kusnetzov@yandex.ru

\section{(C) Ващенко Павел Павлович} капитан медицинской службы, ординатор отделения АиР darmaevad@mail.ru 
С. М. Кузнецов, Ю. С. Косолапов, А. Д. Дармаев и др. Случай успешной реимплантации четвертого пальца правой кисти

\section{(C) Мицкевич Антон Сергеевич}

капитан медицинской службы, начальник отделения анестезиологии и реанимации (АиР) mits.oar38mail.ru

ФГКУ «425 ВГ» Минобороны России филиал № 1 Россия, 664009, г. Иркутск, ул. Госпитальная, 1

Аннотация. В данной статье приводится клиническое наблюдение успешной реимплантации четвертого пальца правой кисти у молодого пациента 30 лет. На первом этапе выполнена имплантация скальпированого мягкотканного остова пальца общехирургическим способом с неудовлетворительным исходом. На втором этапе мягко-тканный покров травмированного пальца восстановлен за счет формирования стебля на ножке за счет тканей передней брюшной стенки. В настоящее время пациент проходит реабилитацию для компенсаторного восстановления функции пальца.

Ключевые слова: травматический отрыв; реимплантация; реабилитация.

\section{Для цитирования}

Случай успешной реимплантации четвертого пальца правой кисти / С. М. Кузнецов [и др.] // Вестник Бурятского государственного университета. Медицина и формация. 2020. Вып. 1. С. 48-56.

Проблема лечения и реабилитации пациентов с травмой кисти в современном мире является очень важной в социальном и экономическом аспектах проблемой. Особенность первой врачебной помощи пострадавшему с ампутацией сегмента конечности заключается в максимально бережном отношении к тканям культи и ампутированного сегмента. Останавливать кровотечение следует наложением давящей повязки или лигированием сосудов в ране. Нет необходимости в первичной хирургической обработке раны. Важна максимально быстрая доставка пациента в специализированное лечебное учреждение вместе с правильно законсервированным отчлененным сегментом. Оптимальным методом консервации ампутата является охлаждение до $+4{ }^{\circ} \mathrm{C}$, не допуская его замораживания. Для этого нужно иметь 2 полиэтиленовых пакета, вложенных один в другой: во внутренний помещают отчлененный сегмент, завернутый в стерильную пеленку или марлю, в наружный - воду с кусочками льда или снега. Прямой контакт тканей сегмента конечности и охлаждающим агентом, а также использование искусственного льда недопустимо. Вопрос о показаниях к операции - один из наиболее сложных в проблеме реплантации. Необходимо учитывать, что главная цель реплантации - полное 
восстановление функции. Один из основных вопросов, который приходится решать при определении показаний к реплантации, - целесообразность операции с точки зрения достижения функционального результата. Именно конечная функция оперированной конечности служит критерием целесообразности выполнения предстоящей операции. При отсутствии послеоперационных осложнений возможна ранняя разработка (сначала пассивная, затем активная) оперированной конечности начиная с 3-4-х суток. Пациентам назначают лечебную гимнастику, массаж, физиотерапию (электрофорез протеолитическими ферментами, аппликация парафина и озокерита, лазеротерапия, локальная вибростимуляция нервов, синусоидальные модулированные токи в сочетании с ультразвуком), механо- и трудотерапию.

Клиническое наблюдение: пациент Л. 30 лет получил обширную скальпированную рану 4 пальца правой кисти с полным циркулярным отчленением мягких тканей до суставов и сухожилий.

Пациент Л. 30 лет 03.09.2019 г. около 18:35, находясь на аэродроме, на стоянке ИАС, при выполнении хозяйственных работ (занимался покрасочными работами), поскользнулся, сорвался со стремянки, упал, зацепившись четвертыми пальцем правой кисти о стремянку. Доставлен в медпункт части, где оказана первая помощь (обезболивание, наложение асептической повязки). Кожный покров четвертого пальца правой кисти помещен в лед для транспортировки. Направлен в филиал № 1 ФГКУ «425 ВГ» Минобороны России, госпитализирован в хирургическое отделение. Рост 177 см, вес 71,5 кг, окружность грудной клетки 99 см. Нормального питания (ИМТ 22,82). Общее состояние удовлетворительное. Сознание ясное. Кожа и видимые слизистые чистые, обычной влажности. Периферические лимфатические узлы не увеличены. Мышечная система развита хорошо. Грудная клетка правильной формы, перкуторно над всеми полями легочной звук, дыхание везикулярное, хрипов нет. Тоны сердца ясные, ритмичные. Пульс 62 уд. в мин., удовлетворительных качеств. Артериальное давление 115 / 75 мм рт.ст. Язык чистый, влажный. Живот обычной формы, не вздут, симметричный, активно участвует в акте дыхания.

Локально: четвертый палец правой кисти полностью лишен кожномягкотканного покрова и представлен костно-сухожильным основанием с сохраненными суставами и пассивными движениями в них и умеренной пердиаледезной кровоточивостью (рис. 1). Отдельно представлен оторванный кожно-мягкотканный покров пальца бледно-розового цвета с темным ногтем и ногтевым ложем (рис. 2). 


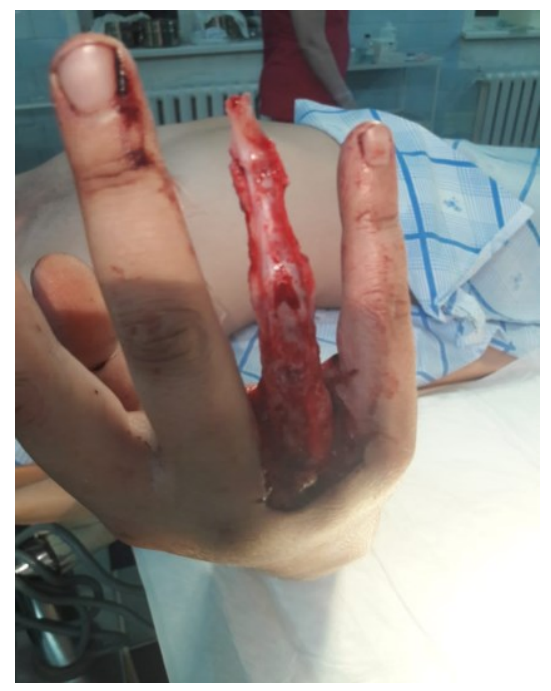

Рис. 1

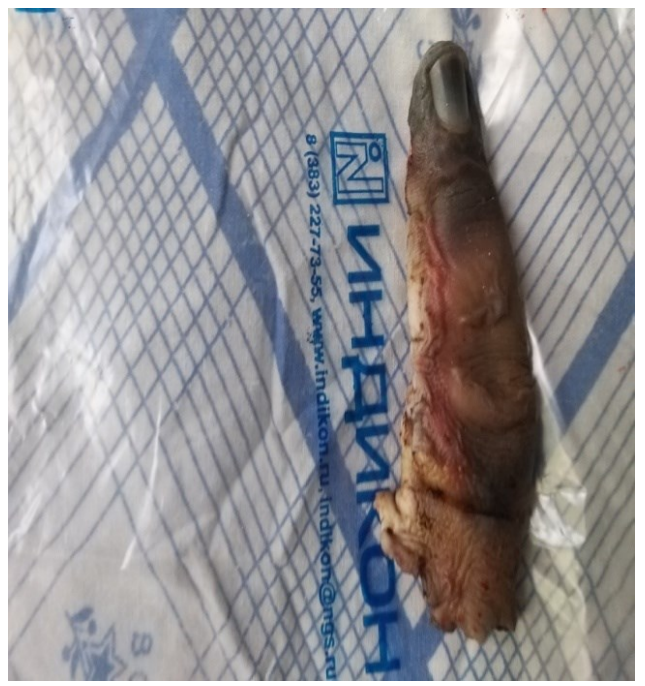

Рис. 2

Проведено лечение: операция (03.09.2019 г.) — хирургическая обработка скелетированной раны четвертого пальца правой кисти с восстановлением кожного покрова свободным лоскутом собственной кожи (рис3.). Предварительно кожно-мягкотканный лоскут санирован трехкратно кожным антисептиком. Выполнено дренирование подсаженного лоскута резиновыми выпускниками (рис. 4). Проводилась консервативная терапия: антибактериальная (Гентамицин по 80 мг. 3 раза в сутки, Линкомицин по 2,0 х 2 раза в сутки), антикоагулянтная и антиагрегантная терапия, ФТЛ, иммобилизация правой кисти гипсовой лонгетой. 06.09.2019 г. на перевязке отмечен некроз подсаженного кожного лоскута в дистальной части и по ладонной поверхности, 09.09.2019 г. отмечен полный некроз подсаженного лоскута (рис. 5). 


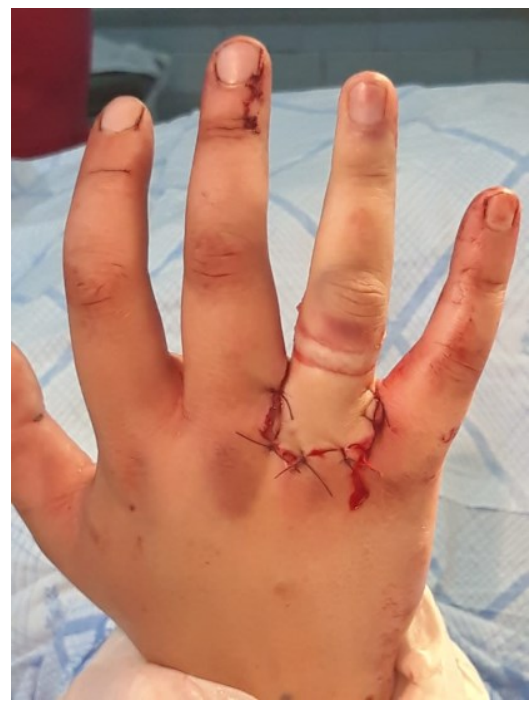

Рис. 3

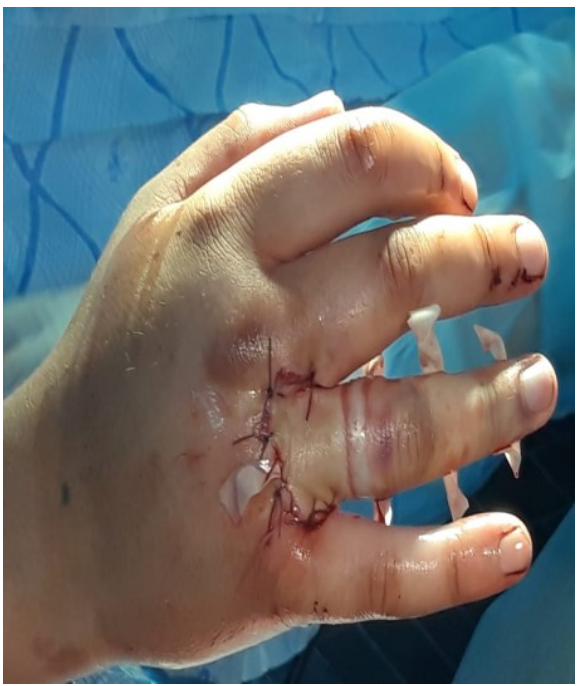

Рис. 4

В связи с чем 09.09.2019 г. по неотложным показаниям выполнена операция: Некрэктомия имплантированного кожного лоскута, экзартикуляция ногтевой фаланги, вторичная хирургическая обработка раны четвертого пальца правой кисти, формирование трубчатого лоскута на ножке на передней брюшной стенки (рис 6.), и реплантация четвертого пальца правой кисти в трубчатый лоскут (рис. 7.)

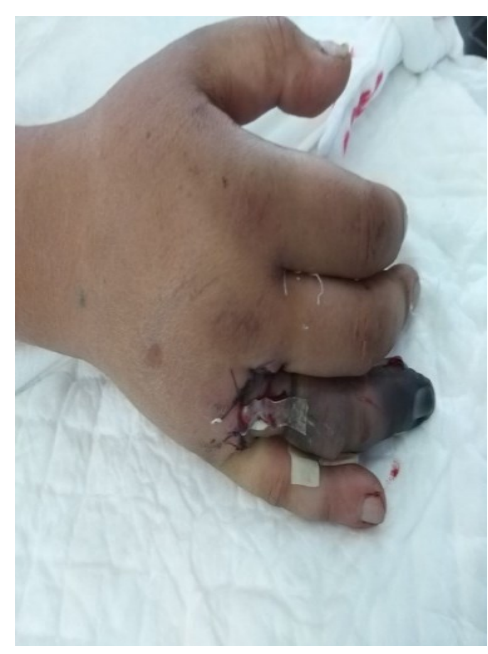

Рис. 5

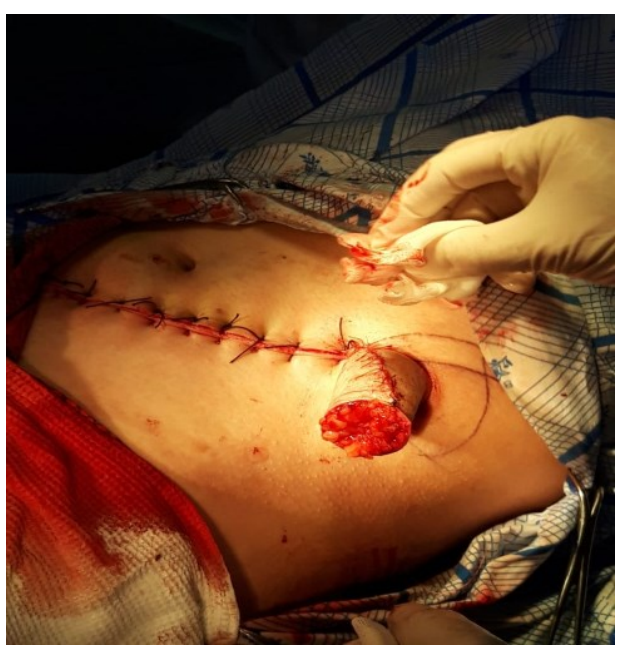

Рис. 6 
С. М. Кузнецов, Ю. С. Косолапов, А. Д. Дармаев и др. Случай успешной реимплантации четвертого пальца правой кисти

При оценке состояния кровоснабжения лоскута на передней брюшной стенке расценено удовлетворительным. Он имеет бледно-розовый цвет, по свободному краю отмечается умеренное поступление артериальной крови. Швы адаптированы хорошо (рис. 8, 9.) Выполнена фиксация верхней конечности к туловищу повязкой типа Вельпо.

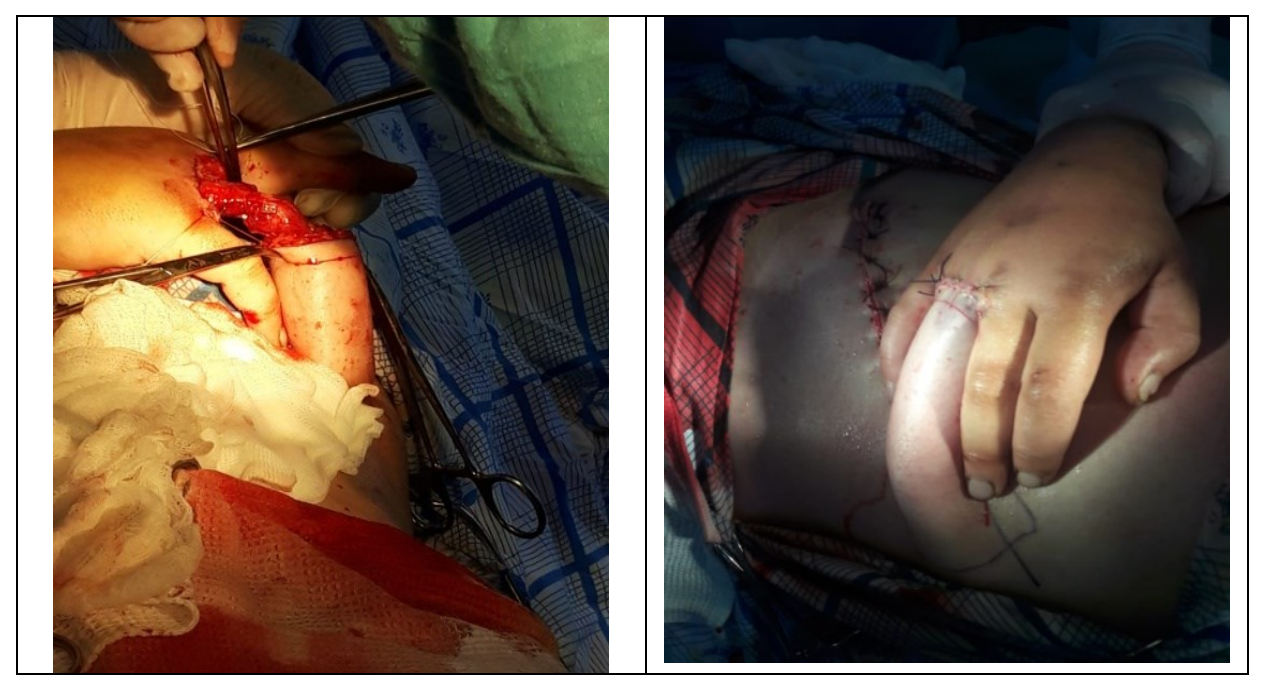

Рис. 7

Рис. 8

В послеоперационном периоде продолжена консервативная терапия. В результате проведенного лечения сформированный стебельчатый лоскут состоятелен; IV палец правой кисти со стебельчатом лоскутом, фиксирующие швы на лоскуте и коже кисти состоятельные без признаков воспаления и нагноения, отека тканей кожи кисти и некроза тканей в области швов не отмечалось; адаптация краев послеоперационной раны на передней брюшной стенки хорошая, формирующиеся рубцы частично под корочками.

С 20.09.2019 г. для дальнейшего обследования и лечения в установленном порядке переведен в специализированное отделение микрохирургии (кисти) ФГБУ «З ЦВКГ им. А. А. Вишневского» Минобороны России. В результате проведенного лечения кровоснабжение в кожном лоскуте адаптировалось через кисть, послеоперационные швы на передней брюшной стенки удалены. 10.10.2019 г. операция: Отсечение лоскута IV пальца правой кисти от питающей ножки. Послеоперационное течение без особенностей, кровоснабжение в кожном лоскуте полностью восстановлено, швы частично удалены. 24.10.2019 г. в удовлетворительном состоянии переведен для этапного лечения в филиал № 1 ФГКУ «425 ВГ» Минобо- 
роны России. 28.10.2019 г. госпитализирован в хирургическое отделение. Проведено лечение: режим, диета, ФТЛ, перевязки. Кроме того, начата разработка функции сухожилий за счет пассивного и активного движения в суставах пальца (рис. 10).

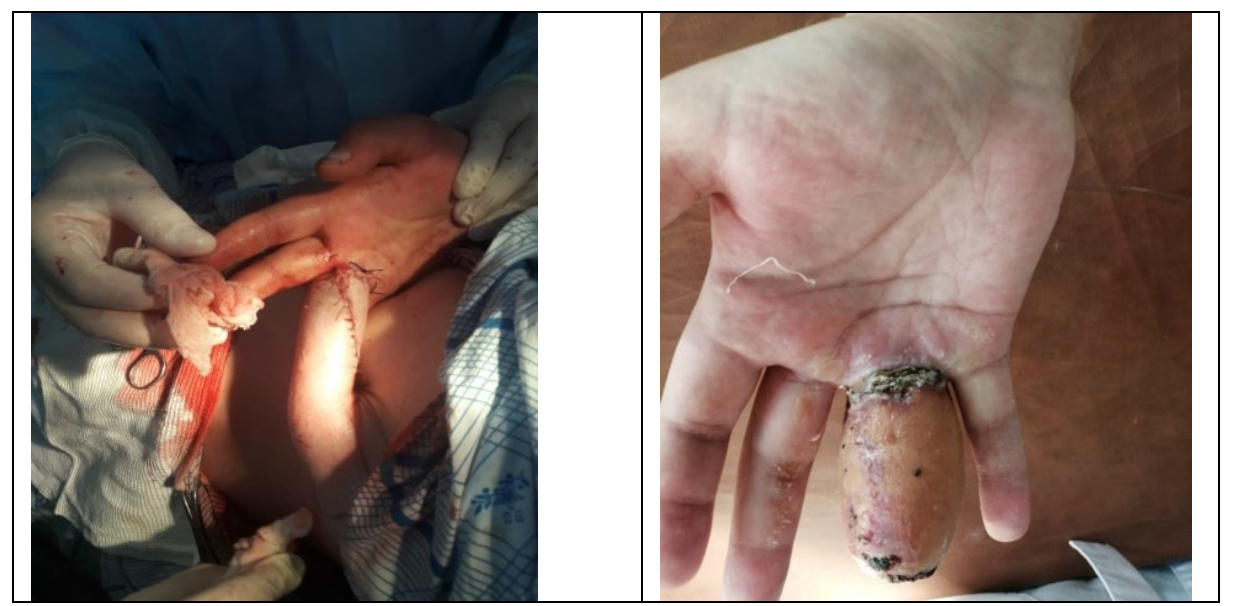

Рис. 9

Рис. 10

Местный статус: IV палец правой кисти покрыт сформированным кожным лоскутом физиологического цвета, теплым, без признаков воспаления и некроза. У основания IV пальца правой кисти на границе сформированного кожного лоскута и кожей кисти по периметру послеоперационный рубец толщиной $0,1 \mathrm{~cm}$, светло-розового цвета без признаков воспаления. По медиально-внутренней поверхности сформированного кожного лоскута от основания до верхней части, окрепший послеоперационный рубец розового цвета толщиной до 0,1 см. На дистальной части кожного лоскута неокрепший послеоперационный рубец 4,0x0,1 см частично под корками. Движения в IV пальце правой кисти ограничены, безболезненные, поверхностная чувствительность кожного лоскута отсутствует, глубокая компрессионная чувствительность IV пальца правой кисти сохранена. Пациенту предстоит активная разработка движений в суставах пальца и ряд косметических операций по формированию ногтя и контуров пальца.

Выводы: Данное клиническое наблюдение показывает, что возможность сохранения функционирующего пальца даже в отсутствии средств микрохирургии возможна. Реабилитационный период при этом длительный и требует настойчивости не только врача специалиста, но и самого пациента для компенсаторного восстановления функции. 
С. М. Кузнецов, Ю. С. Косолапов, А. Д. Дармаев и др. Случай успешной реимплантации четвертого пальца правой кисти

\section{Литература}

1. Азолов В. В., Александров Н. М. Методы реконструкции пальцев кисти при последствиях механической, огнестрельной и термической травмы // Международный медицинский журнал. 2004. Т. 10, № 1. С. 117-123.

2. Березутский С. Н. Применение отсроченной первичной хирургической обработки ран при травмах кисти с дефектами кожи в амбулаторных условиях // Травматология и ортопедия России. 2006. № 2. С. 43.

3. Березутский С. Н., Валовик В. Е. Лечение сочетанных повреждений пальцев кисти // Бюллетень Восточно-Сибирского научного центра СО PAMH. 2007. № 45. С. 29.

4. Басов В. 3., Труханов В. А., Ли С. М. Реабилитация больных с тяжелыми повреждениями кисти и их последствиями // Первый съезд общества кистевых хирургов - кистевая группа. Ярославль, 2006. С. 29-30.

5. Клюквин Ю. И., Мигулева И. Ю., Охотский В. П. Травмы кисти. М.: ГЭОТАР-Медиа, 2009. $188 \mathrm{c}$.

6. Ланцов Ю. А., Маланин Д. А. Восстановление функции суставов пальцев кисти: реальность и перспективы // Бюллетень Волгоградского научного центра РАМН, 2007. С. 18-24.

7. Матвеев Р. П., Петрушин А. Л. Вопросы классификации и терминологии открытых повреждений кисти // Травматология и ортопедия России. 2011. № 2(60). С. 191-198.

\section{CASEO FSUCCESS FULREIMPL ANTATION \\ OF THE FOUR THFINGEROF THE CRIGH THAND BRUSHES}

Kuznetsov S. Mironovich

Doctor of Higher Category, Head of Operational Department,

Sociate Professor,

s.m.kusnetzov@yandex.ru

Kosolapov Yu. Leonidovich

Lieutenant Colonel of Medical Service,

Senior Intern, Surgeon of the Highest Category

y.kosolapov@mail.ru

Darmayev A. Dashievich

Doctor Neurologist of the Highest Category

Darmaevad@Mail.Ru 
Gordeenok F. Demidovich

Resident at the Surgical Department

Honorary Doctor of Russia, Doctor of Higher Category

elenabotoeva@list.ru

Loginov O. Stanislavovich

Surgeon Polyclinic Department

Doctor of Higher Category

elenabotoeva@list.ru

Zyryanov A. Anatolevich

resident of the Depsrtament of Anasthesiology

s.m.kusnetzov@yandex.ru

Vashchenko P. Pavlovich

captain of the Medical Service Resident

at the Department of Anesthesiology and Resuscitation

darmaevad@mail.ru

Branch 1 Fgku «425-Vg» Mo RF

1, Hospital Str., Irkutsk, 664009, Russia

Abstract.In the data the articie provides clinical observation of successful reimplantation of the fourth finger of the right hand in a 30 year old young patient. The first stage is completedimplantation of a scalped soft-tissue finger skeleton using a General surgical method with an unsatisfactory outcome. At the second stage, the softwoven cover of the tissues of the anterior abdominal wall. The patient is currently undergoing rehabilitation for compensatory restoration of finger fuction.

Keywords: traumatic separacion; reimplantation; rehabilitation. 